\title{
Publiczność i proksemika posiedzeń sejmowych, czyli wybrane aspekty przestrzeni społecznej parlamentarnych wystąpień posłów
}

Katarzyna Kostrzewa

Uniwersytet Łódzki

Abstrakt. Artykuł koncentruje się na próbie zrekonstruowania przestrzeni społecznej obrad sejmowych. Dwa kluczowe wymiary tej przestrzeni, które zostały przeanalizowane, to: środowisko proksemiczne sali posiedzeń, wraz z charakterystycznymi obszarami, takimi jak centrum, peryferia, kulisy, granice oraz publiczność obrad sejmowych będąca elementem kontekstu dla wystąpień posłów. Charakterystyka wymienionych elementów ma prowadzić do próby odpowiedzi na pytanie, w jaki sposób swoiste cechy przestrzeni społecznej posiedzeń Sejmu mogą wpływać na jakość debaty parlamentarnej.

Słowa kluczowe: przestrzeń społeczna, środowisko proksemiczne, analiza przestrzeni, publiczność, reakcje publiczności, emocje w interakcjach, wystąpienia sejmowe 


\section{Wprowadzenie}

Główny przedmiot mojej analizy określić można jako przestrzeń społeczną. Na wstępie uargumentuję zasadność użycia tego sformułowania, podam jego zakres znaczeniowy oraz postaram się odpowiedzieć na pytanie, dlaczego przestrzeń jest społeczna. Aby w pełni przeanalizować interakcje na sali sejmowej, powinniśmy się przyjrzeć przestrzeni społecznej w dwojaki sposób: jako miejscu wytworzonemu przez daną grupę społeczną, któremu wyznaczyła ona funkcję i nadała znaczenie; oraz jako metaforycznemu ujęciu sieci wzajemnych relacji i specyficznego podłoża, na którym rozgrywają się działania społecznych aktorów (Jałowiecki, Szczepański 2006: 316). W praktyce oznacza to, że analiza będzie odnosiła się do rozmieszczenia posłów w przestrzeni sali sejmowej i czynników, które to rozmieszczenie determinują. Metaforyczne ujęcie przestrzeni społecznej opiszę z punktu widzenia wzajemnych wpływów i relacji pomiędzy przemawiającymi na mównicy posłami a publicznością tych wystąpień ${ }^{1}$. Interakcje są zatem uzależnione od przestrzeni społecznej w jej fizycznym oraz metaforycznym wymiarze.

Literatura socjologiczna podaje kilka uzasadnień dla społecznej natury przestrzeni. Przede wszystkim, przestrzeń jest s p ołecznie wytworzona (Jałowiecki, Szczepański 2006: 316) - ludzie w toku jej kreowania, adaptacji wchodzą ze sobą w określone interakcje. Spoglądając jeszcze inaczej, możemy powiedzieć, że aktorzy społeczni w trakcie interakcji adaptują i reorganizują przestrzeń. Także posłowie $\mathrm{w}$ trakcie obrad podporządkowują

1 Przestrzeń społeczna posiedzeń sejmowych w ujęciu metaforycznym - sieć wzajemnych relacji między aktorami społecznymi - opisywana jest także w pozostałych częściach niniejszej książki. Rozdział ten koncentruje się jedynie na relacji mówca-publiczność. Ciekawe wydają się także inne zależności, które daje się dostrzec w trakcie posiedzeń sejmowych, m.in. marszałek-publiczność, marszałek-mówca, partia rządząca-opozycja. 
sobie przestrzeń sali sejmowej. Wydarzenie, jakim jest posiedzenie Sejmu, staje się okazją do tego, by pewien obszar (przestrzeń w sensie fizycznym) stał się miejscem społecznych interakcji. Obszar sali sejmowej nie jest już wtedy tylko zwykłą powierzchnią, lecz miejscem, przestrzenią znaczącą (Bierwiaczonek 2004: 127).

Kolejnym uzasadnieniem badania przestrzeni jako zjawiska o naturze społecznej jest fakt, że charakteryzują ją specyficzne rodzaje ludzkich działań (Jałowiecki, Szczepański 2006: 316). Określenie przestrzeni pracy, odpoczynku, modlitwy, obszarów sacrum i profanum odbywa się dzięki ludzkim aktywnościom, które te obszary kategoryzują. Bez nadanych im wartości byłyby one jednakie. Podobnie dzieje się z przestrzenią sali sejmowej, której nadaje się określony charakter i kontekst. Zasady i normy, które zaczynają organizować interakcje na tej przestrzeni, sprawiają, że zyskuje ona pewne symboliczne znaczenie. Jak pisze Marta Cobel-Tokarska (2012: 46): „Nie badamy już tylko przestrzeni «obiektywnej»- wysokości, długości i szerokości, które zawsze da się odmierzyć tak samo, ale miasta, wsie, cmentarze, domy, ulice, place, wnętrza biur - czyli przestrzeń, w której toczy się ludzkie życie. Człowiek staje się twórcą przestrzeni, którą zamieszkuje, zagospodarowuje, dzieli, w której odbywa interakcje. Przestrzeń rozpatrujemy zatem jako dzieło i arenę życia człowieka”. Ciekawa okazuje się także refleksja, w jaki sposób przestrzeń ta może wpływać na przebieg i kształt obrad Sejmu.

Drugim kluczowym punktem artykułu będzie próba zrekonstruowania roli publiczności w trakcie wystąpień sejmowych. Określenie przestrzeń społeczna ma także „[...] sens czysto metaforyczny i znaczy tyle co pewien wymiar rzeczywistości społecznej" (Jałowiecki 2002: 241). Dzięki temu możliwy będzie opis uwzględniający współwystępowanie cech przestrzennych i społecznych (ibidem). Reakcje publiczności stają się tłem dla 


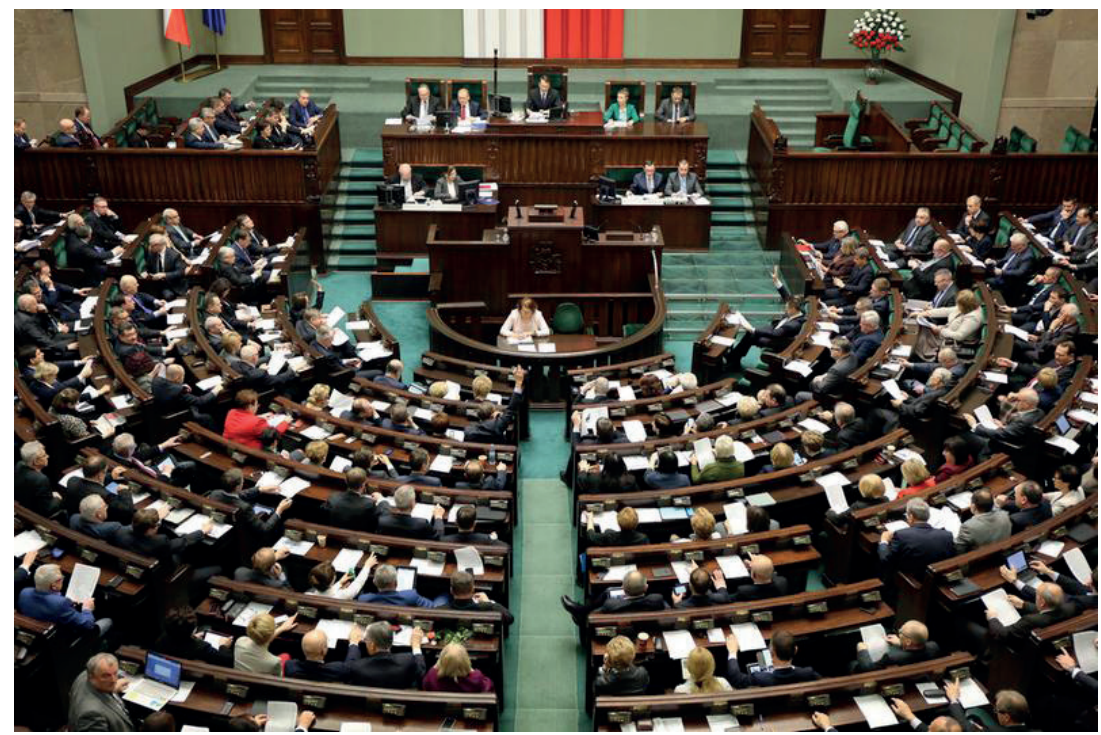

Fot. 1. Zdjęcie sali posiedzeń Sejmu

Źródło: http://www.sejm.gov.pl/Sejm7.nsf/galleries.xsp

rozgrywanych wydarzeń i w dużej mierze warunkują przebieg i odbiór wystąpień posłów. Analiza polegać będzie na zbudowaniu typologii najczęstszych reakcji audytorium oraz próbie odpowiedzi na pytanie, w jaki sposób ta specyficzna przestrzeń społeczna wpływać może na przebieg interakcji, którą za Ervingiem Goffmanem zdefiniować należy jako „wzajemny wpływ na swe postępowanie jednostek znajdujących się w bezpośredniej fizycznej bliskości” (Goffman 2008: 45). W trakcie interakcji jednostki odgrywają przypisane sobie role, które niczym wzór działania ujawniający się w czasie występu określa szereg elementów. Jednym z nich jest f a s a d a, którą E. Goffman określa jako standardowe środki wyrazu stosowane przez jednostkę, celowo lub mimowolnie, podczas występu. Dekoracja, meble, sprzęty, 
rekwizyty sceniczne wykorzystywane przez jednostkę $\mathrm{w}$ trakcie wystąpienia ${ }^{2}$ stają się fasadą, która poprzez nagromadzenie symboli pozwala jednostce na stworzenie u partnerów interakcji odpowiednich wrażeń. Istotnymi elementami fasady są także powierzchowność i sposób bycia (Goffman 2008: 45-52).

\section{Społeczne kształtowanie przestrzeni}

Odwołując się do dorobku socjologów przestrzeni (zob. Yi-Fu Tuan 1987; Jałowiecki, Szczepański 2006), można wyróżnić następujące kategorie analizy: położenie, granica, kierunek, przejście, centrum i peryferia.

Centrum, będąc miejscem naładowanym znaczeniami symbolicznymi, oznacza potęgę, władzę, daje poczucie możliwości wpływu oraz korzystania z różnego rodzaju udogodnień (Jałowiecki, Szczepański 2006: 324). Centrum określa także orientację pozostałych punktów i ich istotność. Wyznacza położenie bliskie lub dalekie, centralne lub peryferyjne. Dychotomia ta wprowadza dystans, którego percepcja, czyli ocena tego, czy punkt jest położony blisko czy daleko, ma w przypadku przyswajania przestrzeni charakter społeczny, a zarazem względny (Jałowiecki, Szczepański 2006: 322). Położenie może być także definiowane poprzez kierunek, a szczególnie opozycję góra-dół. „Kategoria wertykalna (pionowa) jest najważniejsza - nie tylko organizuje i hierarchizuje świat społeczny, lecz także go wartościuje" (Cobel-Tokarska 2012: 50).

Kolejnymi przydatnymi kategoriami mogą okazać się pokrewne terminy: przejście i granica. Pierwszy z nich wskazuje na

2 Występy - wszelka działalność danego uczestnika interakcji w danej sytuacji służąca wpływaniu w jakiś sposób na któregoś z innych jej uczestników (Goffman 2008: 45). 
przerwanie ciągłości przestrzennej, drugi natomiast sygnalizuje utrudnienia w dostępie do przestrzeni (Jałowiecki, Szczepański 2006: 326). Granice stają się kluczowe „[... ] do określenia tożsamości (gdzie kończymy się «my», a zaczynają «oni») dla poczucia bezpieczeństwa, integralności, a także orientacji. Mogą być formalne i nieformalne, fizyczne i umowne; różnią się także szczelnością, a określane przez nie obszary - poziomem otwartości/ izolacji. To, co za granicą, bywa postrzegane jako niebezpieczne" (Cobel-Tokarska 2012: 50).

Wszystkie wymienione kategorie odgrywają ważną rolę w procesie postrzegania, wytwarzania, naznaczania i przyswajania przestrzeni, są głęboko zakodowane w psychice i doświadczeniu, zatem jednostki dostrzegają je podświadomie i traktują naturalnie. Gdy któryś z wymienionych elementów nie jest wystarczająco wyartykułowany, reagują uczuciem zagubienia i niepokoju (Jałowiecki, Szczepański 2006: 327). Naturalne granice, miejsce centralne, odległości pozwalają dokonać kategoryzacji miejsc zajmowanych przez posłów.

W niniejszej analizie chciałabym także odwołać się do prac teoretyków, którzy zajmowali się relacją pomiędzy fizycznym wymiarem przestrzeni a funkcjonowaniem jednostki. Nawiązując do prac E. Goffmana, można stwierdzić, że przestrzeń, na której rozgrywają się działania aktorów, buduje odpowiednią fasadę - kontekst wystąpień - poprzez określanie miejsc przeznaczonych dla przemawiających, marszałków, posłów. „Dekoracja znajduje się na ogół w tym samym miejscu, tak że ci, którzy chcą ją wykorzystać do swojego występu, nie mogą zacząć gry, zanim nie znajdą się we właściwym miejscu, i opuszczając je, muszą kończyć swój występ” (Goffman 2008: 52). Pisząc o przestrzeni, nie sposób nie odwołać się także do rezultatu pionierskich badań Edwarda T. Halla. Autor terminu proksemika stwierdza, że bliskość przestrzenna bądź jej brak są bardzo istotnymi warunkami wpływającymi na interakcje jednostek. Ludzie wyko- 
rzystują przestrzeń, aby się komunikować. Charakter przestrzeni oddziaływa na aktorów społecznych. Całość fizycznie obecnego i dostępnego tła interakcji nazwać możemy środowiskiem proksemicznym (Leathers 2007: 113).

\section{Przestrzeń w perspektywie interakcjonistycznej}

Socjologia interakcji pomaga w zrozumieniu zależności pomiędzy przestrzenią a zachowaniem jednostki. Przede wszystkim środowisko fizyczne człowieka i tożsamość oddziałują na siebie. Przestrzeń zawiera i komunikuje podzielane symbole i znaczenia, które jak wiadomo stają się podstawą ładu społecznego. Zaprojektowane środowisko nie stanowi tylko i wyłącznie tła dla ludzkich zachowań - wręcz przeciwnie, działa jak czynnik, który kształtuje sposób myślenia i działania, skłaniając do autorefleksji.

Mary Jo Hatch - używając teorii interakcjonistycznej jako perspektywy badawczej - pokazuje, w jaki sposób organizacje wpływają na swoich członków poprzez architekturę. Zaprojektowane środowisko pracy wysyła liczne sygnały, które komunikują oczekiwania wobec ról aktora społecznego i otaczających go jednostek. Jako przykład autorka podaje boksy biurowe, mające na celu podkreślenie standaryzacji i rutynizacji pracy, lub umiejscowienie przestrzeni przeznaczonej dla kadry zarządzającej na najwyższych piętrach budynków (za: Bugni i Smith 2006: 133).

Model porządku społecznego oraz podział przestrzeni publicznej na kulisy i scenę odpowiadają optyce, która wiąże się z występowaniem, odgrywaniem określonych ról. Koncentrując się na wymiarze rytualnym wystąpień sejmowych, uzasadnione będzie analizowanie ich w kategorii spektaklu. Goffmanowska perspektywa zakłada, że aktorzy społeczni podczas zbiorowych 
działań kierują się określonymi regułami i zasadami, zaś ich aktywności w obrębie zgromadzeń nie są przypadkowe. Dramaturgiczne spojrzenie na grupę aktorów społecznych umożliwia odkrycie interesującej wiedzy o mechanizmach (nie do końca wprost sformułowanych i uświadomionych), które wpływają bezpośrednio na ich zachowanie (zob. Goffman 2008). Opisywany przez Goffmana model porządku społecznego to wytwór każdego zespołu norm, określający, w jaki sposób ludzie organizują własne aktywności i jak dążą do swoich celów. Ważne jest to, że model dramaturgiczny podkreśla koordynację i integrację sposobów, w jaki te cele można osiągnąć. Zakłada, że działania przebiegają zgodnie z regułami porządku społecznego (Goffman 2008: 11). Warto wspomnieć, że porządek publiczny odnosi się do bezpośrednich interakcji między członkami społeczeństwa, którzy nie znają się osobiście zbyt dobrze. W sytuacji interakcji z obcymi aktorami społecznymi należy zastosować zasady, które ułatwią wzajemne kontakty. Zarządzanie wrażeniem, jak pisze E. Goffman, to wysiłek, jaki jednostki ponoszą, aby wywrzeć wrażenie podczas wystąpień, do których wykorzystują elementy otoczenia, takie jak: rozmieszczenie, umeblowanie, dekoracje i pozostałe elementy stanowiące ramy dla organizacji sceny (za: Bugni i Smith 2006: 126).

W trakcie obrad sejmowych dochodzi do funkcjonalnego podziału na scenę i kulisy. Kategorie te można połączyć ze wspomnianymi już obszarami centralnymi i peryferyjnymi. Scena byłaby zatem tożsama z centrum, zaś kulisy z peryferiami. Każda jednostka, znając nacechowanie i znaczenie przestrzeni, znajdując się wśród innych, świadomie lub nieświadomie projektuje definicję sytuacji, której istotną składową stanowi jej koncepcja samej siebie (Goffman 2008: 311). Po raz kolejny przekładając to na grunt badań i analiz będących tematem tej pracy stwierdzam, że autodefinicja aktora społecznego jest silnie powiązana $z$ tym, czy znajduje się on za kulisami czy w samym centrum sceny. Usytuowanie w przestrzeni wpływa na definiowanie siebie. E. Goff- 
man wspomina także o możliwości wewnętrznych podziałów wśród uczestników zgromadzenia (Goffman 2008: 22). Tak właśnie dzieje się pośród posłów, gdy umiejscawiani są w przestrzeni zgodnie z pełnionymi przez nich funkcjami oraz przynależnością partyjną.

\section{Analiza przestrzeni proksemicznej sali sejmowej}

\subsection{Centrum}

Analizę przestrzeni sali sejmowej rozpocząć należy od centrum, którym niewątpliwie jest miejsce przeznaczone dla Marszałka Sejmu, będącego najwyższym przedstawicielem izby niższej parlamentu. Kierując pracami Sejmu, odgrywa on rolę strażnika jego praw i godności. Miejsce marszałka, usytuowane na podwyższeniu w centralnej części sali, jest jej najlepiej widocznym punktem. Zgromadzeni posłowie, usytuowani niżej niż marszałek (fot. 1), muszą dostosować się do reguł narzucanych przez marszałka, który zwołuje posiedzenia Sejmu, przewodniczy obradom, czuwa nad terminowością prac, a w trakcie zgromadzeń udziela prawa głosu. Marszałek Sejmu kształtuje zatem przebieg obrad i jest odpowiedzialny za sprawną pracę zgromadzenia (fot. 3). Posiedzeniom Sejmu przewodniczą także wicemarszałkowie, których liczba zwyczajowo odpowiada liczbie partii politycznych. Skład Prezydium Sejmu w trakcie przeprowadzanej analizy stanowili: Marszałek Sejmu Ewa Kopacz oraz wicemarszałkowie: Cezary Grabarczyk, Marek Kuchciński, Wanda Nowicka, Jerzy Wenderlich, Eugeniusz Grzeszczak. Władza marszałka nad przebiegiem obrad łączy się z odpowiedzialnością za dyscyplinę wśród posłów, zarówno tych przemawiających, jak i zasiadających w ławach poselskich. Marszałek nadaje rytm obradom, 


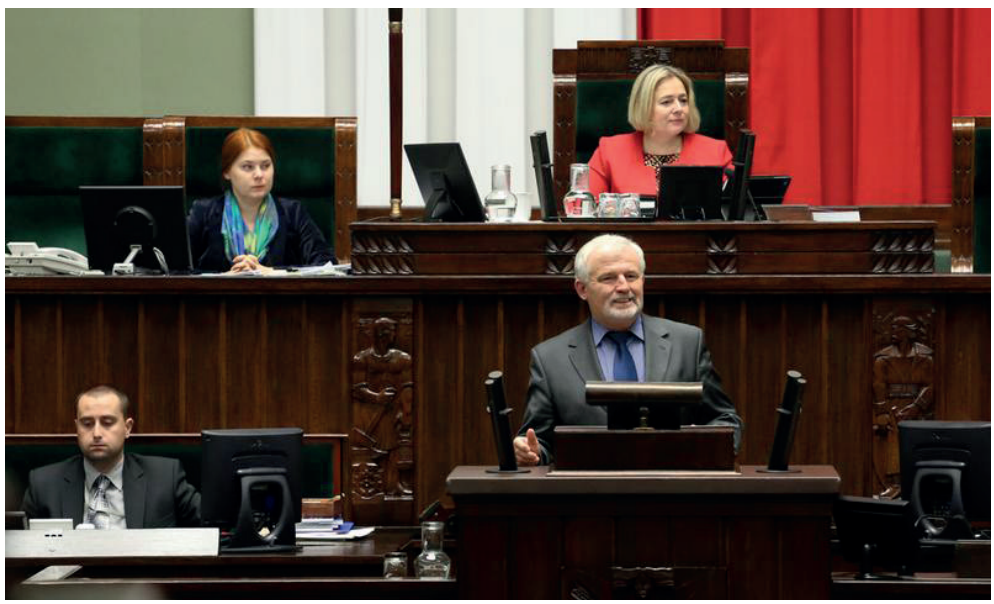

Fot. 2. Podwyższone miejsce symbolizuje hierarchię oraz dodaje powagi funkcji pełnionej przez Marszałka (spoglądającego „z góry” na przemawiającego)

Źródło: http://www.sejm.gov.pl/Sejm7.nsf/galleries.xsp?rok=2013

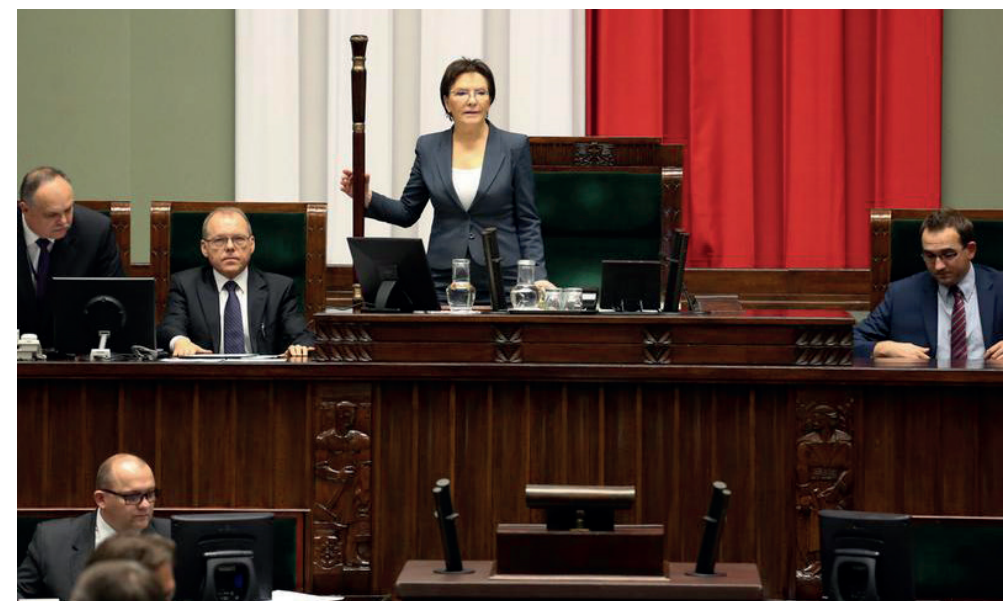

Fot. 3. Centrum sali sejmowej - miejsce Marszałka Sejmu oraz atrybuty władzy marszałkowskiej: laska marszałkowska oraz fotel

Źródło: http://www.sejm.gov.pl/Sejm7.nsf/galleries.xsp?rok=2013 
przywołuje do porządku, gani, udziela kar oraz, jeśli to konieczne, pilnuje czasu wystąpień. Odnosząc się do tego, w jaki sposób jednostki odbierają sygnały płynące z przestrzeni, zaznaczyć należy, że podwyższone i centralnie usytuowane miejsce marszałka dodaje jego roli powagi i stanowczości (fot. 2). Podobną funkcję pełnią atrybuty władzy marszałkowskiej: laska marszałkowska (symbol władzy marszałka) oraz fotel marszałka (fot. 3). Nasuwają one skojarzenia $z$ architektonicznymi artefaktami, o których pisze E. Goffman, stwierdzając, że stanowią symbole statusu pozwalające na podkreślenie pozycji społecznej (za: Bugni i Smith 2006: 132). Ten sam autor nazywa r e ży s e r e m osobę pełniącą doniosłą funkcję przywoływania do porządku uczestników wystąpienia, którzy niewłaściwie odgrywają narzuconą im rolę, poprzez uspokajanie, karanie, rozładowywanie napięcia i przywoływanie do porządku (Goffman 2008: 127). Określenie to nasuwa oczywiście skojarzenia z funkcją Marszałka.

$\mathrm{Na}$ potrzeby spektaklu, jakim jest niewątpliwie posiedzenie Sejmu, uwaga widzów zostaje także skierowana na drugi punkt centralny - mównicę - miejsce wystąpień posłów. Osoby przemawiające usytuowane są na podwyższeniu, poniżej miejsca Marszałka, pośrodku sali. Przemówienia skupiają uwagę publiczności oraz bywają przez nią żywiołowo komentowane, nagradzane lub wyśmiewane. Oko kamery jest niemal stale zwrócone na mównicę. Występujący posłowie muszą zdawać sobie sprawę, iż każdy ruch oraz gest mogą być zarejestrowane i poddane surowej ocenie. 


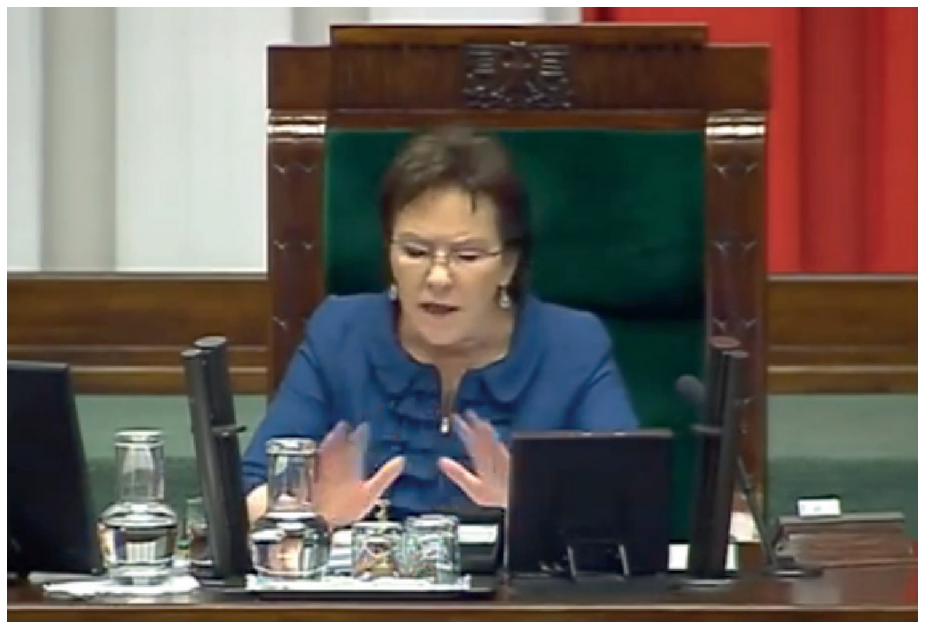

Fot. 4. Przywilej centrum - kierowanie przebiegiem obrad. Marszałek Kopacz zwraca się do posła Kopycińskiego, który łamie regulamin i zaburza porządek obrad: „Nie, Panie Pośle, zabieram Panu głos. Naprawdę, zabieram Panu głos. Nie!”

Źródło: https://www.youtube.com/watch?v=NoR2AOG4wkl

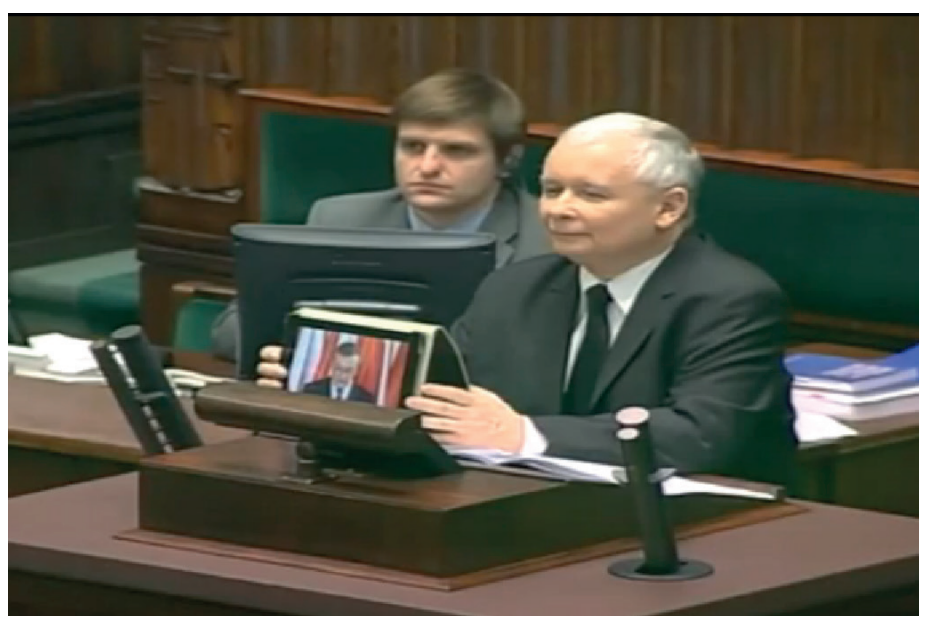

Fot. 5. Centrum, aktor i atrybut - Jarosław Kaczyński prezentuje na tablecie film Źródło: www.youtube.com/watch?v=u73e2oxeneQ 
Przebywanie na mównicy jest równoznaczne z prawem głosu, które ograniczane bywa jedynie przez Marszałka. Przemowy nasuwają skojarzenia $\mathrm{z}$ wystąpieniami aktorskimi. Aktorzy-politycy modulują odpowiednio głos, gestykulują, kierują swoje wypowiedzi do realnie obecnej publiczności (posłowie w ławach) oraz do publiczności wyobrażonej (widzowie telewizyjni, odbiorcy transmisji obrad z sali sejmowej). Bywa, że aktorzy zwiększają siłę swojego wyrazu, posługując się atrybutami, takimi jak tablety, na których prezentują multimedialne treści, czy „niewygodnymi prezentami" dla partii opozycyjnych ${ }^{3}$.

Po udzieleniu prawa głosu posłowi uwaga publiczności skierowana jest na jego osobę. Dzieje się tak również wtedy, gdy przemawiający zmienia miejsce i dynamikę wystąpienia, kierując uwagę publiczności w stronę innych posłów. Przykładem takiego zwrotu akcji może być wręczenie ministrowi Nowakowi pluskwy w słoiku przez posła Jakiego. Występujący opuścił mównicę i skierował się w stronę miejsc rządu. Wydarzeniu towarzyszyły oklaski. Premier, minister Nowak oraz minister Sikorski przyglądali się bacznie słoikowi, po czym na ich twarzach pojawiły się uśmiechy. Za sprawą działań przemawiającego posła także oni znaleźli się niespodziewanie w centrum wydarzeń.

Kolejnym elementem organizującym przestrzeń sali sejmowej są granice, które także w znacznym stopniu służą podkreśleniu wagi miejsc centralnych i peryferyjnych. Przykładem granic są przejścia między ławami posłów, które organizują przestrzeń dla publiczności. Granice oddzielają posłów zrzeszonych w obrębie jednej partii od pozostałych parlamentarzystów. Jest to symboliczne podkreślenie podziałów na konkretne frakcje wewnątrz izby mniejszej.

3 Poseł Jaki wręczył Premierowi i Ministrowi Transportu robaka zamkniętego w słoiku w związku ze znalezieniem pluskwy w przedziale pociągu pasażerskiego. 


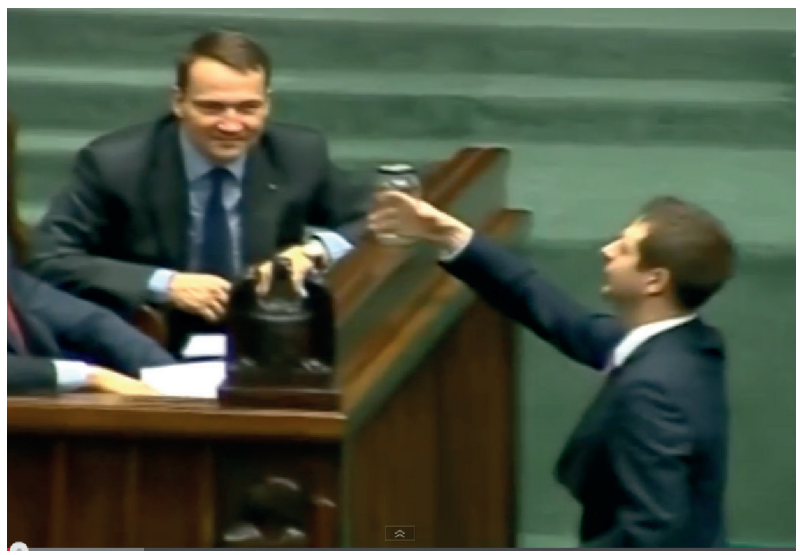

Fot. 6. Zmiana centrum wydarzeń i użycie atrybutu występu. Poseł Jaki do Ministra Transportu: „Chciałbym przekazać panu ministrowi prezent, który podarowali mi pasażerowie, pasażerowie Polskich Kolei, pasażerowie relacji Olsztyn-Wrocław. Prosili, aby przekazać Panu pasażera, który zajął ich miejsce, jak wsiadali do pociągu. Uwaga, i to jest pluskwa"

Źródło: www.youtube.com/watchv=0JPMMiYp5-Y

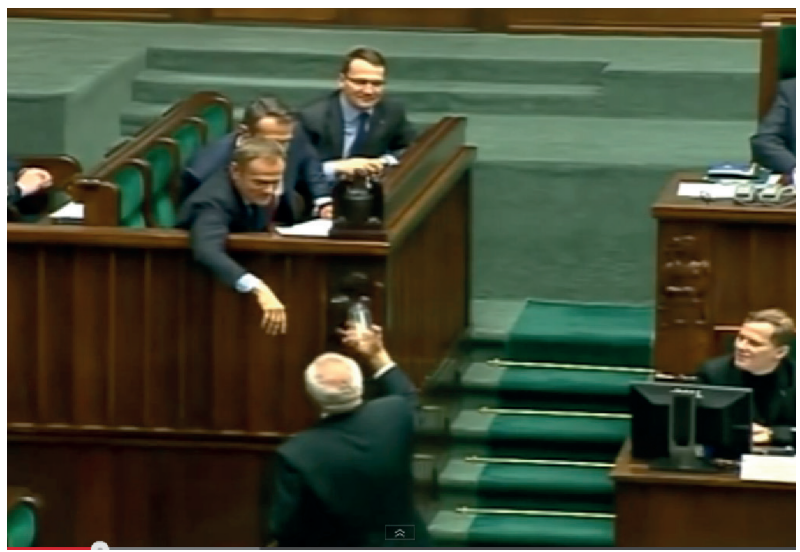

Fot. 7. Posłowie/publiczność w centrum wydarzeń. Poseł Niesiołowski komentuje wydarzenia: „To jest karaluch”

Źródło: www.youtube.com/watchv=0JPMMiYp5-Y 


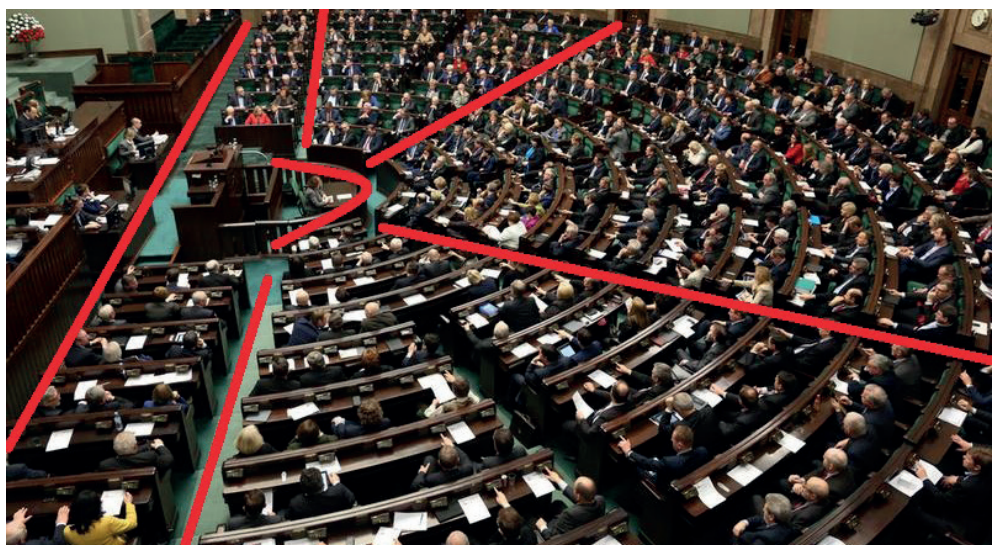

Fot. 8. Część przejść na sali sejmowej wyznacza frakcje polityczne Źródło: http://www.sejm.gov.pl/Sejm7.nsf/galleries.xsp?rok=2013

Pozostałe granice, które odnajdujemy na sali sejmowej, odgradzają przestrzeń obradujących od miejsc przeznaczonych dla gości i mediów. Osoby te w żaden sposób nie uczestniczą w odgrywanym spektaklu. Nie mają też żadnego wpływu na jego przebieg.

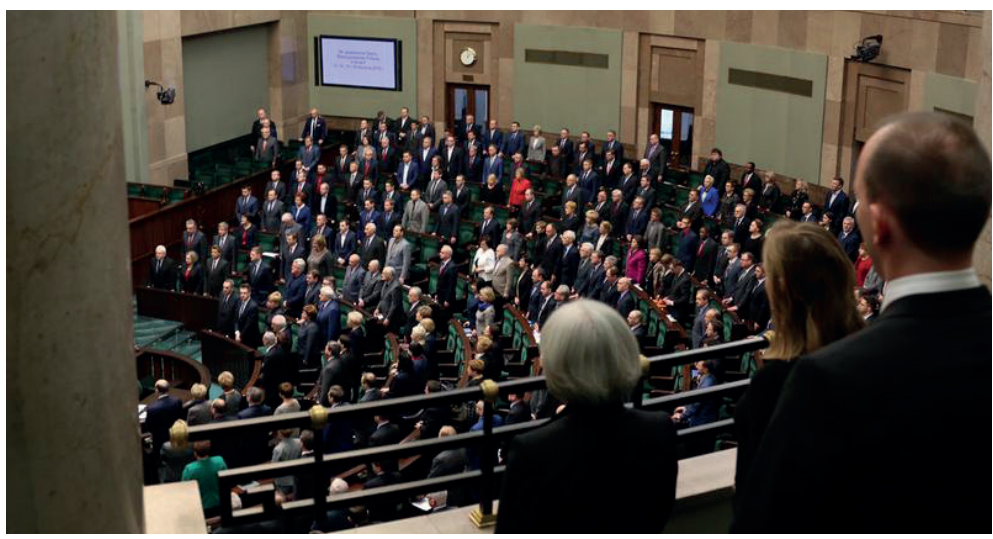

Fot. 9. Poza granicami - miejsca przeznaczone dla gości i mediów Źródło: http://www.sejm.gov.pl/Sejm7.nsf/galleries.xsp?rok=2013 


\subsection{Publiczność}

Posłowie zasiadający w ławach poselskich tworzą peryferia spektaklu - publiczność. E. Goffman definiuje widownię jako osoby uwikłane w interakcje i występy na zasadzie współuczestnictwa (Goffman 2008: 45). Przekonani o tym, że nie znajdują się w centrum uwagi, zachowują się swobodniej niż w trakcie wystąpień. Często rozmawiają, korzystają z urządzeń mobilnych, czytają prasę. Ich obserwowalne dla kamery zaangażowanie $\mathrm{w}$ obrady wydaje się być znikome (fot. 10). Dzieje się tak, ponieważ dystans fizyczny decyduje o sile społecznego wpływu. Organizacja przestrzeni może zakłócać częstotliwość i jakość społecznych interakcji (Brand 2009: 2).

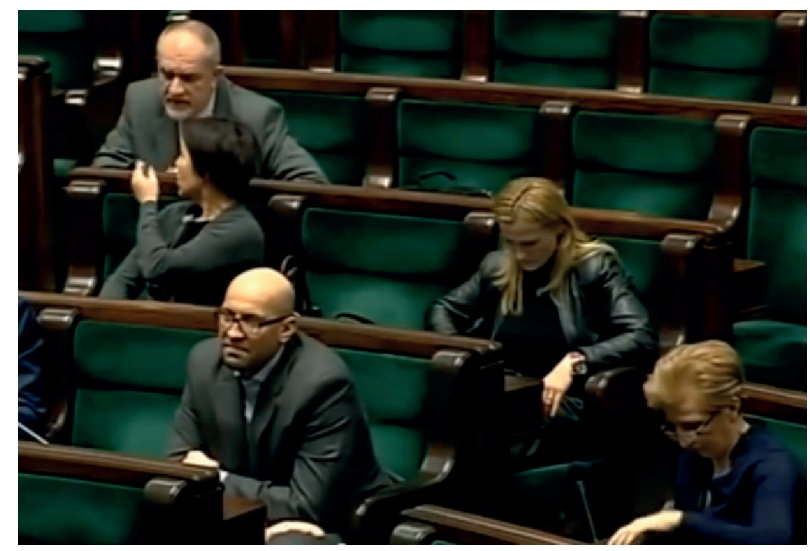

Fot. 10. Publiczność/peryferia

Źródło: www.youtube.comwatch/v=wnOMCC1GPTE

Publiczność, pomimo peryferyjnego usytuowania, odgrywa ważną rolę - staje się „interpretującym tłem” dla wydarzeń i wystąpień skoncentrowanych wokół mównicy. Jej zachowanie nadaje kontekst wystąpieniom poprzez spontaniczne komentarze, 
jakimi są brawa, śmiech, szum rozmów lub oburzenia. Także liczebność zgromadzonych osób jest wyrazem wagi poruszanych w wystąpieniach tematów. Jak zatem widać w przypadku zgromadzeń sejmowych, publiczność jest niezwykle ważnym elementem, tłem, które nadaje kontekst dla wystąpień posłów.

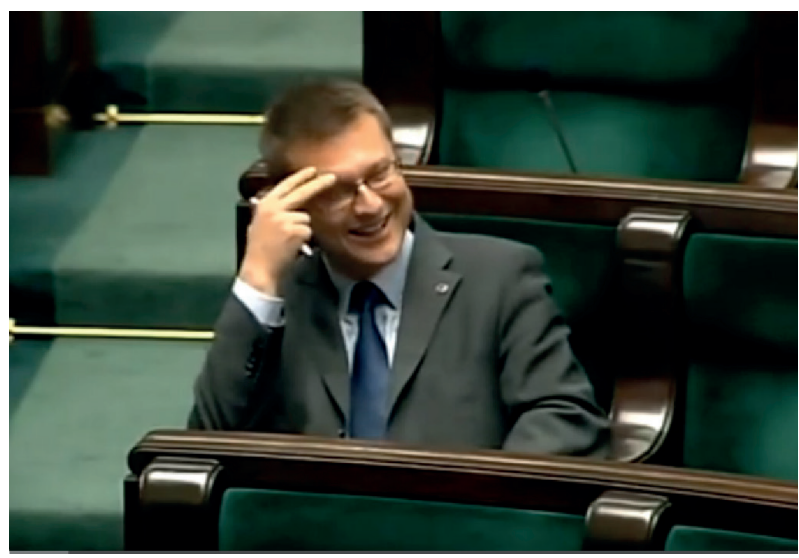

Fot. 11. Reakcje publiczności stają się tłem dla rozgrywanych wydarzeń. Poseł Dunin z PO śmieje się w trakcie wystąpienia poseł Pawłowicz: „Najwyższe zdumienie budzi śmiałość przedstawiania sejmowi projektów prawnych, które tak rażąco są sprzeczne z polską Konstytucją". Tym samym podaje w wątpliwość zasadność i rzetelność wypowiadanych słów

Źródło: www.youtube.com/watchv=wnOMCC1GPTE

\section{Rola publiczności w przebiegu obrad sejmowych}

W trakcie każdego posiedzenia Sejmu mamy do czynienia ze specyficznym rodzajem wystąpienia, któremu towarzyszy publiczność. Telewizyjne transmisje stwarzają przede wszystkim okazję do zaistnienia publiczności złożonej z telewidzów lub 
internautów. Z drugiej strony, nie można zapominać o publiczności uczestniczącej w obradach Sejmu. Posłowie, którzy nie pełnią funkcji marszałka lub wicemarszałków oraz w danym momencie nie przemawiają, stanowią specyficzne audytorium. Jak już to zostało wcześniej wspomniane, stanowią tło dla rozgrywających się na sali sejmowej wydarzeń. Wyobrażona lub rzeczywiście współobecna publiczność wpływa na zachowania aktorów społecznych.

Analizie poddano filmiki, fragmenty transmisji posiedzeń Sej$\mathrm{mu}$, zamieszczone na kanale YouTube. Kamera przedstawia jedynie wycinek sytuacji komunikacyjnej, który naturalnie uniemożliwia poznanie szerszego kontekstu, a także znacznie redukuje liczbę obserwacji.

\subsection{Telewidzowie - publiczność wyobrażona}

Zajmując się analizą przekazów medialnych, należy zastanowić się nad tym, jak charakter specyficznego kontekstu komunikowania masowego może wpłynąć na działania aktorów społecznych. Tło sytuacji, w jakiej znajdują się jednostki, silnie oddziałuje na ich język, repertuar gestów oraz podejmowane tematy wystąpień.

Podstawową kwestią techniczną, która określa konstruowanie tekstów w komunikacji masowej, jest stosowanie technicznych środków przekazu, które przyspieszają transmisję oraz zwiększają liczbę nadawanych komunikatów. Przeładowane informacjami treści szybko docierają do odbiorców, zaś duża konkurencja wśród nadawców sprawia, że przekaz szybko traci na aktualności. Instytucjonalny charakter nadawcy oraz masowość odbiorcy wymuszają istnienie osób, które odgrywają rolę pośredników w kontakcie (Skarżyńska 2010: 114). Spikerzy, prezenterzy, gospodarze programów telewizyjnych, pełniąc te funkcje, są jednocześnie odpowiedzialni za kształt języka w mediach. Wspomniana już mnogość informacji sprawia, że komunikowanie 
w mediach musi przyciągać widzów atrakcyjnością formy, zaś sam język wraz ze słownictwem powinny być proste w odbiorze. Szybkość w przyswajaniu przekazów masowych gwarantuje używanie wyrazistego ogólnego słownictwa, prostej, logicznej składni, zwięzłość i skrótowość tekstów oraz redukcja skomplikowanej terminologii. Zainteresowanie przekazem uzyskiwane jest dzięki używaniu utartych zwrotów frazeologicznych, które przyciągają uwagę, ale zarazem nie utrudniają zrozumienia. Funkcjonalizacja i czytelność wspomnianych składników osiągane są poprzez ich konwencjonalizację i szablonowość (Furman, Kaliszewski, Wolny-Zmorzyński 2006: 182).

Współcześnie nadawcy medialni stają także przed całkiem nowymi wyzwaniami. Coraz bardziej obowiązująca staje się potrzeba demokratyzacji przekazu, zbliżenia się do odbiorcy za sprawą indywidualnego stylu w wypowiedzi dziennikarskiej (Furman, Kaliszewski, Wolny-Zmorzyński 2006: 183). Elementy takie ożywiają komunikat, uwiarygodniają go i zbliżają nadawcę do widza. Rozważając wpływ natury przekazów medialnych, warto wspomnieć także o tym, jak kształt grupy docelowej programów telewizyjnych może wpłynąć na ostateczny kształt języka prezenterów. Twórcom treści medialnych zależy na dopasowaniu do grupy docelowej. Bezpośrednim skutkiem tych starań może okazać się dążenie do naśladowania wyobrażonego sposobu komunikowania się potencjalnych widzów programu.

Bez wątpienia politycy przemawiający w trakcie obrad Sejmu zdają sobie sprawę, że ich wystąpienia, za sprawą mediów, mogą dotrzeć do szerokiego grona odbiorców. Wrażenie, jakie stwarzają w trakcie przemówień, prezentowane treści oraz stosunek do przeciwników politycznych wpływają na opinie wyborców. W związku z tym zabiegi oratorskie, stosowane porównania, zarzuty i usprawiedliwienia muszą być prezentowane w sposób, który zapewni łatwe dotarcie do telewidzów. Wspomniana już demokratyzacja przekazu kształtuje wypowiedzi posłów zgod- 
nie z omówionymi regułami wystąpień telewizyjnych. Stosowana przez posłów ironia czy elementy nowomowy są tego niewątpliwym przykładem.

Odpowiednie wrażenie powinny stwarzać na telewidzach także komunikaty niewerbalne przemawiających posłów. Osoby, które chcą być postrzegane jako asertywne i stanowcze, powinny posługiwać się następującymi sygnałami (Leathers 2007: 107):

1) spójność werbalnych i pozawerbalnych komponentów przekazu;

2) rozluźnienie gestów i postaw;

3) ciało nachylone do przodu;

4) stanowcza, ale nie ekspansywna gestykulacja;

5) podtrzymywanie kontaktu wzrokowego;

6) podkreślające kluczowe słowa ilustratory lub wokalna modulacja;

7) odpowiednio donośny głos.

Część posłów świadomie panuje nad swoim ciałem i gestami, wzbudzając u widzów wrażenie osób przekonanych o słuszności wypowiadanych opinii. Kontrolowanie ekspresji pozwala także na uniknięcie niezręczności będącej dowodem utraty kontroli ${ }^{4}$ nad ciałem. Zająknięcie, zapomnienie roli, okazanie zdenerwowania, zmieszanie czy skrępowanie mogą świadczyć o nadmiernym lub niedostatecznym przejęciu się interakcją. Kontrola nad ciałem i fasadą związana jest także z dbaniem o spójność i kierunek wystąpienia, które zakłócone mogą być przez niegotową scenerię czy wejście w nieodpowiednim momencie (Goffmann 2008: 82). Z samokontrolą występujących wiąże się również pojęcie pracy nad emocjami, które Arlie Russell Hochschild

4 E. Goffman podaje liczne przykłady utraty kontroli nad ciałem w trakcie interakcji: potknięcie, ziewnięcie, czknięcie, drapanie, wzdęcie, zderzenie $z$ inną osobą. 
(2009) opisała jako wysiłek, jaki jednostka musi włożyć w dopasowanie swoich emocjonalnych reakcji do wyznaczanych przez społeczeństwo norm. Praca nad ciałem służąca opanowaniu emocjonalnych reakcji fizycznych, dobór odpowiednich gestów, które mają pogłębić pożądane emocje, oraz intencjonalna praca nad wzbudzaniem określonych stanów emocjonalnych poprzez przywoływanie wspomnień pozwalają jednostce dopasować się do społecznie definiowanej kultury emocji. Pojęcie to w ujęciu Hochschild (2009) oznacza zespół podzielanych wyobrażeń dotyczących tego, jakie emocje powinna odczuwać jednostka w określonej sytuacji. Rola polityka zakłada więc pełną kontrolę nad niepożądanymi reakcjami emocjonalnymi, takimi jak zdenerwowanie, poirytowanie szmerami ze strony publiczności. Emocje, którymi może wykazać się poseł w trakcie wystąpienia, to między innymi gniew czy sprzeciw wobec niemoralnych działań opozycji.

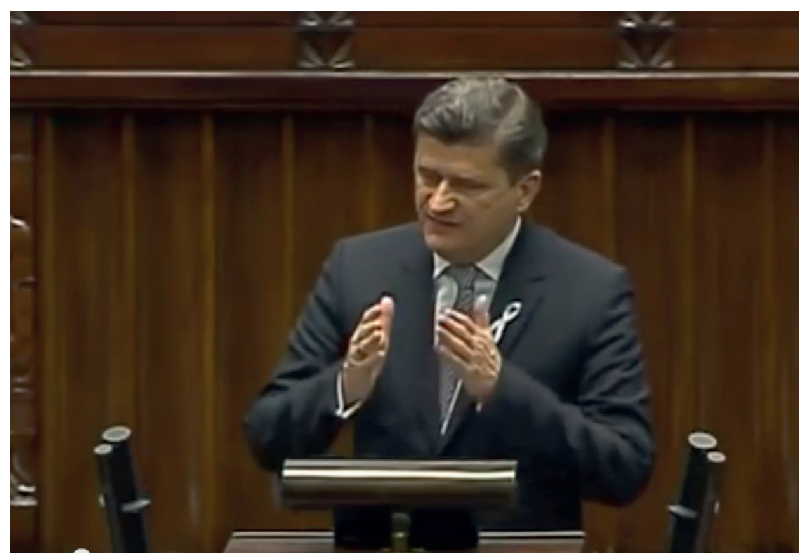

Fot. 12. Poseł Palikot podkreśla kluczowe słowa gestykulując. Ostro ocenia reformę emerytalną: „To jest świętokradztwo”. Stanowcza i asertywna postawa Źródło: www.youtube.comwatchv/C5yFa1saJjE 


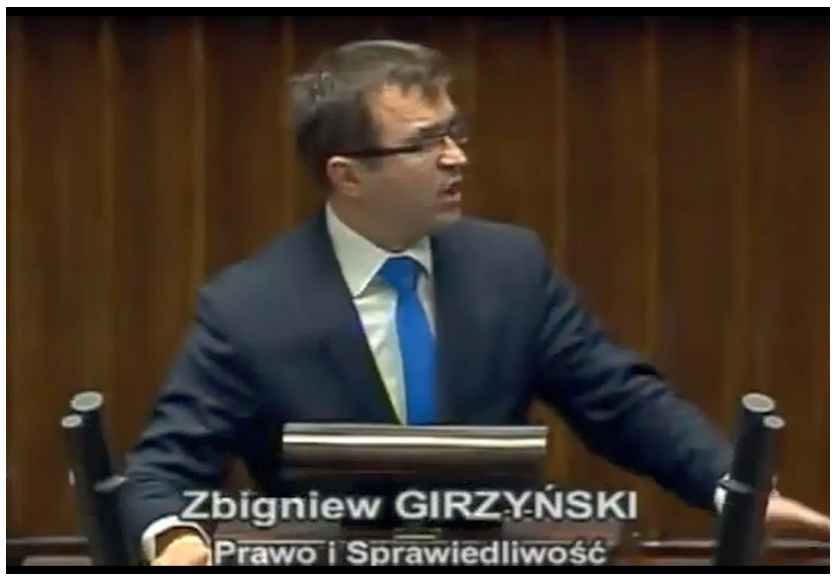

Fot. 13. Poseł Zbigniew Girzyński utrzymuje kontakt wzrokowy z publicznością zgromadzoną po lewej stronie sali. Ciało pochylone do przodu. Stanowcza i asertywna postawa

Źródło: www.youtube.comwatchv=LjpmUW4olh0

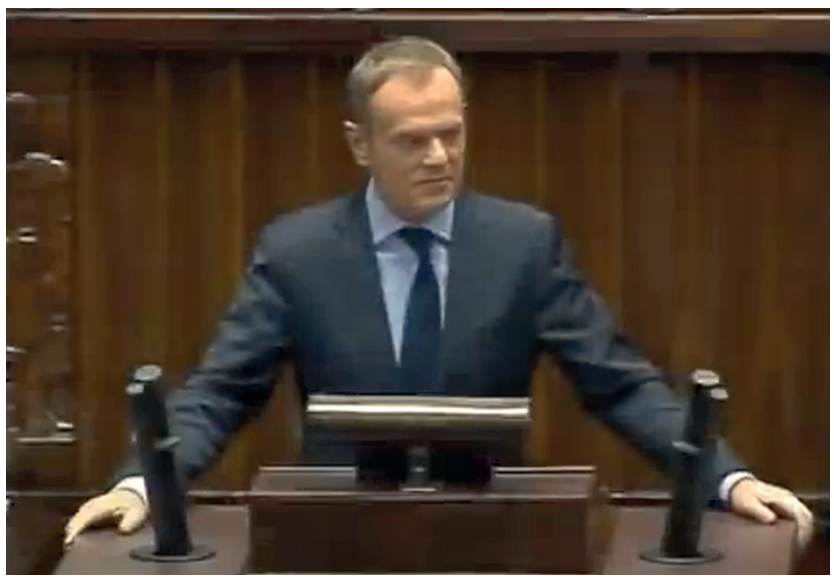

Fot. 14. Premier Tusk - otwarta postawa ciała, kontakt wzrokowy z publicznością. Stanowcza i asertywna postawa. Wystąpienie towarzyszące głosowaniu nad wnioskiem o odwołanie ministra zdrowia Bartosza Arłukowicza

Źródło: www.youtube.comwatchv=kLrM-SOfpjk 


\subsection{Posłowie - publiczność na sali sejmowej}

Audytorium zgromadzone na sali sejmowej, w przeciwieństwie do publiczności telewizyjnej, ma możliwość w sposób aktywny oddziaływać na przebieg wystąpień posłów. Swoimi spontanicznymi reakcjami może zakłócać ich wystąpienia, nagradzać trafne repliki lub spontanicznymi komentarzami reagować na kontrowersyjne wypowiedzi.

Zaobserwowany repertuar możliwych reakcji publiczności zdecydowałam się podzielić na dwa rodzaje:

1. Reakcje pozytywne:

- oklaski;

- śmiech nagradzający.

2. Reakcje negatywne:

- rozmowy/szmer;

- śmiech/wyśmiewanie;

- ostentacyjne opuszczanie sali obrad.

\subsection{Pozytywne reakcje publiczności}

Za przykład pozytywnej reakcji publiczności niewątpliwie możemy uznać oklaski. Jest to jedno z najbardziej spontanicznych zachowań, wyrażające aprobatę dla czyjejś osoby lub wystąpienia. Zauważyć można jednak, że oklaskami (mimo ich spontanicznego i dobrowolnego z natury charakteru) publiczność nagradza jedynie występujących przedstawicieli własnego klubu.

Oklaski publiczności są dla wystąpienia pozytywnym tłem świadczącym o słuszności głoszonych stwierdzeń i sądów. Przemawiający swoją intonacją zdają się wskazywać momenty odpowiednie na przerwę zapełnioną oklaskami. Publiczność bezbłędnie odgaduje te sugestie. Innym przejawem pozytywnej reakcji publiczności, który często towarzyszy oklaskom, jest śmiech będący reakcją na trafną, żartobliwą replikę, zabawną uszczypliwość 
skierowaną w stronę politycznych oponentów. Nagradzający śmiech publiczności jest potwierdzeniem dla racji oraz oratorskich zdolności występujących (fot. 15). Świadczy o słuszności prezentowanych treści oraz akceptacji publiczności dla głoszonych hipotez i ocen. Pozytywne reakcje możemy uznać za przykład dramatyzacji działań aktora, które E. Goffman (2008: 60) określa jako „znaki pozwalające dramatycznie oświetlić i wydobyć z cienia przemawiające na jej [jednostki] korzyść fakty, które w innym wypadku mogłyby pozostać niewidoczne lub niezauważone”. Poboczna rola „klakiera”, działającego w porozumieniu z występującymi, dostarcza pożądanego przez wykonawcę wzoru reagowania na występ (Goffman 2008: 174).

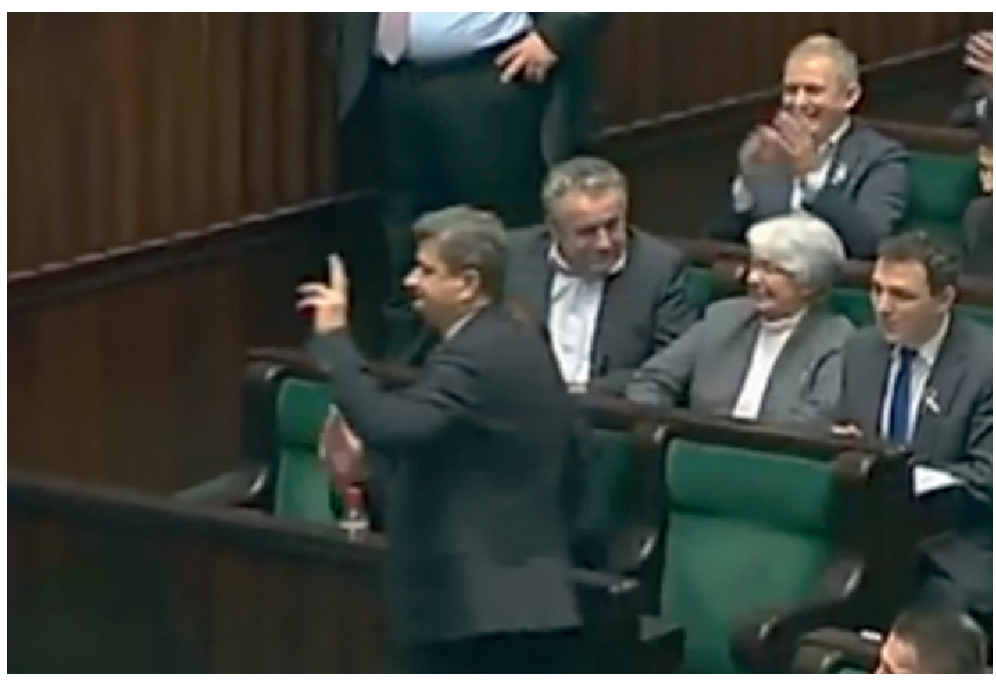

Fot. 15. Poseł Miller zwraca się z mównicy do posła Palikota słowami Juliana Tuwima: „Próżnoś repliki się spodziewał. Nie dam ci prztyczka ani klapsa. Nie powiem nawet pies cię..., bo to mezalians byłby dla psa". Słowa wzbudzają rozbawienie posłów SLD. Poseł Palikot wyraża swój sprzeciw

Źródło: www.youtube.comwatchv/C5yFa1saJjE 


\subsection{Negatywne reakcje publiczności}

Negatywne reakcje publiczności mają na celu dyskredytowanie wystąpień posłów przeciwnych partii. Krytyczne oceny mogą się przejawiać w lekceważeniu występujących lub w okazywaniu sprzeciwu wobec prezentowanych sądów.

Rozmowy oraz towarzyszący im szmer w trakcie wystąpień posłów są sygnałem wskazującym na znudzenie publiczności, który świadczy o lekceważącym podejściu do przemawiających. Przykładem takiego zachowania jest wystąpienie posła Jakiego podczas posiedzenia, na którym dyskutowany był temat wotum nieufności dla ministra Nowaka. Posłowie zgromadzeni wśród publiczności rozmawiali, nie zważając na obecność posła Jakiego na mównicy. W trakcie transmisji telewizyjnej dało się słyszeć szmer rozmów ze strony audytorium.

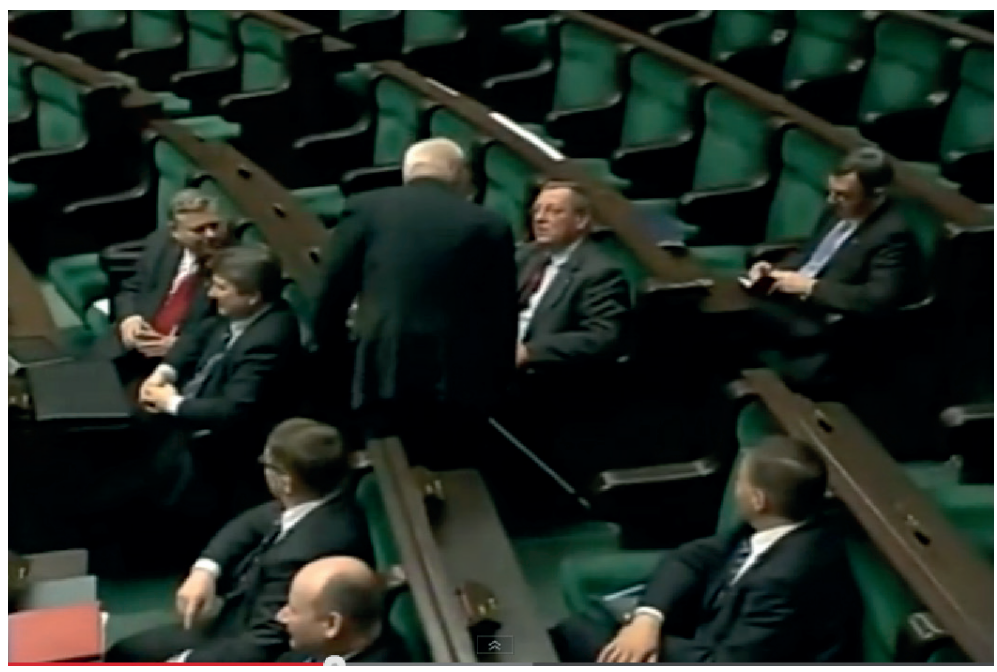

Fot. 16. Rozmowy posłów w trakcie wystąpienia posła Patryka Jakiego Źródło: www.youtube.comwatchv=0JPMMiYp5-Y 
Występujący posłowie mogą w dwojaki sposób ustosunkować się do zakłóceń dobiegających ze strony publiczności. Niektórzy starają się nie zauważać towarzyszących szmerów i rozmów (poseł Jaki, fot. 17), inni aktywnie uciszają przeszkadzających kolegów (poseł Kaczyński, fot. 18). Nawiązując do opisywanych już komunikatów niewerbalnych, stwierdzić można, iż poseł Jaki ignorując rozmowy posłów, spuszcza wzrok, spogląda w kartkę, myli się w swojej wypowiedzi. Prezentuje postawę niepewną siebie, unika konfrontacji z publicznością. Doświadczony polityk, jakim jest niewątpliwie Jarosław Kaczyński, ucisza publiczność gestami oraz słownie przywołuje do porządku.

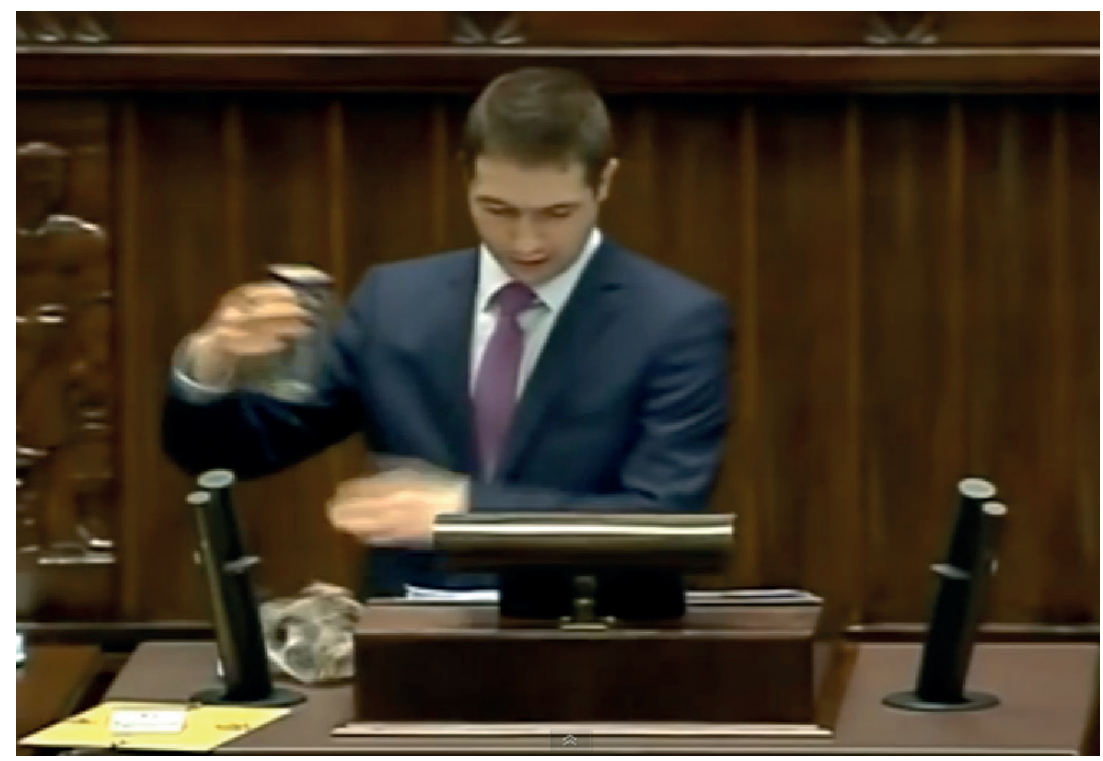

Fot. 17. Poseł Jaki spuszcza wzrok, ignoruje szmer publiczności

Źródło: www.youtube.comwatchv=OJPMMiYp5-Y 


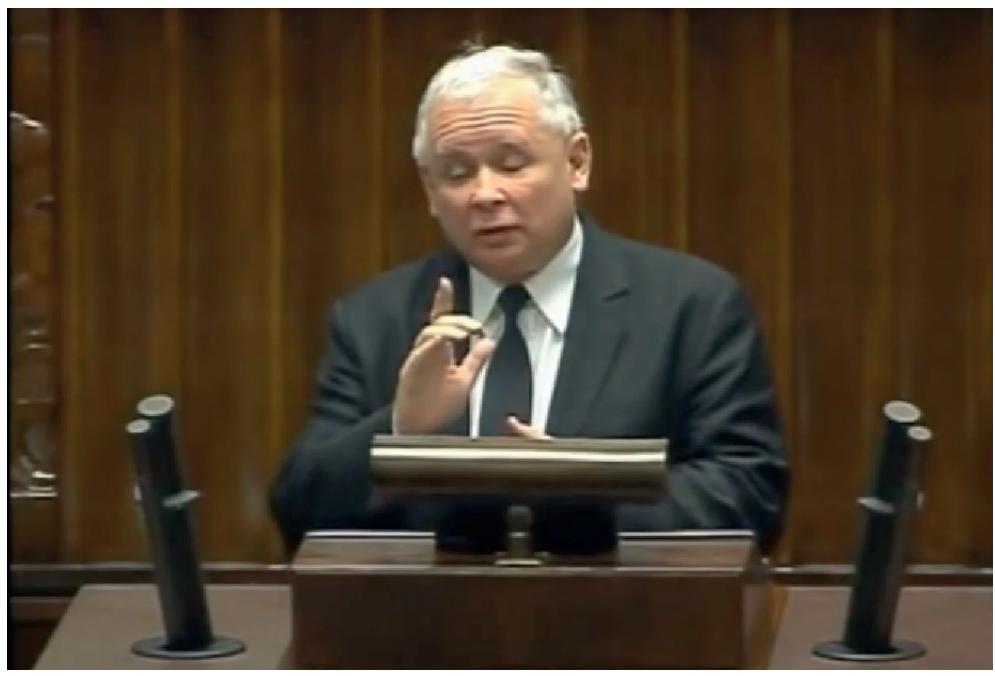

Fot. 18. Jarosław Kaczyński ucisza rozmowy publiczności: „Ćśś, powtarzam, ponieważ ten pan, który tam siedzi [wskazuje na Premiera, słychać buczenie wśród publiczności], o nazwisku Tusk, wymienił moje nazwisko"

Źródło: www.youtube.comwatchv=GroeGfOijWI

Dyscyplinowaniem niesubordynowanych reakcji audytorium zajmuje się także Marszałek Sejmu Ewa Kopacz. Działo się tak chociażby w trakcie wystąpienia Jarosława Kaczyńskiego, w którym prezes PiS oskarżycielskim tonem podsumowywał rządy Platformy Obywatelskiej. Podczas przemówienia ze strony publiczności dało się słyszeć okrzyki „złodzieje” (fot. 19). W instytucji Marszałka skupiają się w szczególny sposób działania mające na celu zapobieganie załamywaniu się definicji sytuacji. Praktyki zapobiegawcze i praktyki korekcyjne mają na celu utrzymanie prawidłowego wrażenia i uniknięcie kłopotliwych sytuacji (Goffman 2008: 43). Marszałek Ewa Kopacz rozładowuje napięcie poprzez przerwanie krzyków oburzenia ze strony publiczności: „Potrzebujecie Państwo przerwy, żeby trochę sobie pokrzyczeć?" (fot. 19). 


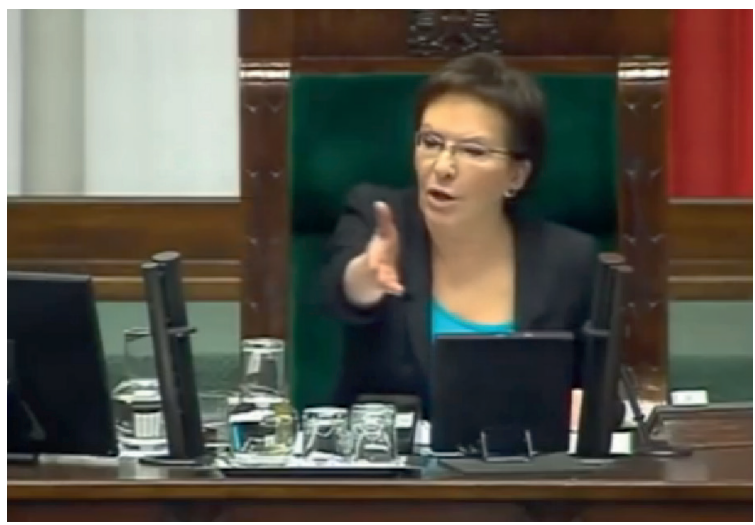

Fot. 19. Marszałek Sejmu reaguje na krzyki publiczności, zwraca się do poseł Kempy, która zmierza w stronę mównicy. „Pani Poseł, bardzo proszę. [dzwonek] Potrzebujecie Państwo przerwy, żeby trochę sobie pokrzyczeć?”

Źródło: www.youtube.comwatchv=GroeGfOijWI

Opisane zachowania są przykładem aktywnego i głośnego manifestowania swoich poglądów przez zgromadzonych zasiadających w ławach poselskich. Zdarza się, że osoby spośród audytorium, postępując wbrew procedurom, stają się centrum wydarzeń. W trakcie wystąpienia posła Jakiego na temat wotum zaufania dla ministra Nowaka, poseł Niesiołowski, z racji swojego wykształcenia, został nieformalnie poproszony przez premiera Donalda Tuska o ocenę zwierzęcia, które minister transportu otrzymał w prezencie od przemawiającego. Po bacznej obserwacji, zarejestrowanej przez oko kamery, poseł Niesiołowski, pomimo braku mikrofonu, głośno zwrócił się do występującego właśnie posła: „Naucz się biologii nieuku”. Także premier Donald Tusk pozwala sobie na głośną odpowiedź w trakcie prezentowania zarzutów przez Jarosława Kaczyńskiego. Jak zatem widać, publiczność, pomimo braku drogi formalnej do bezpośredniego komentowania wystąpień innych posłów, często impulsywnie ustosunkowuje się do prezentowanych treści. Można stwierdzić, że przestrzeń jest w tym przypadku definiowana na bie- 
żąco. Politycy wybierają przestrzeń przeznaczoną do innych celów, by prezentować publicznie swoje poglądy. Omijają trybunę i wypowiadają się wprost z miejsc przeznaczonych dla publiczności. Warto zaznaczyć, że łamią w ten sposób dyscyplinę sejmową, za co niejednokrotnie są przywoływani do porządku i karani przez Marszałek Sejmu. Opisane sytuacje nasuwają skojarzenia $\mathrm{z}$ opisanymi przez E. Goffmana dyskredytacjami definicji sytuacji. „Kiedy dochodzi do tego rodzaju wstrząsów, interakcja ulega zatrzymaniu na skutek konfuzji i zakłopotania. Część założeń, na podstawie których przewidywano reakcje uczestników interakcji, okazuje się nie do utrzymania, oni sami zaś odkrywają, że są uwikłani w interakcję, w której sytuacja była źle zdefiniowana, a teraz w ogóle zdefiniowana nie jest" (Goffman 2008: 52). Na podobne sytuacje anomii i zburzenia założonego przebiegu sytuacji jednostka reaguje zagubieniem. Poseł Jaki na niespodziewaną krytykę ze strony posła Niesiołowskiego odpowiada zawstydzeniem. Zgodnie z założeniami roli, jako przemawiający, powinien posiadać wyłączne prawo do wypowiedzi. W związku z tym reakcja posła Niesiołowskiego w dwójnasób zakłóca definicję sytuacji. Przede wszystkim wypowiada się jednostka, która nie jest w danym momencie do tego upoważniona. Co więcej, charakter wypowiedzi posła Niesiołowskiego podważa kompetencje i merytoryczne przygotowanie przemawiającego.

Kolejną negatywną reakcją na wystąpienia posłów jest śmiech. W przeciwieństwie do opisywanego już pozytywnego śmiechu, reakcji na trafny żart, śmiech ten jest wynikiem lekceważącego ustosunkowania się do prezentowanych treści lub oskarżeń. Fałszywy śmiech może być także, jak piszą Suzzanne Retzinger i Thomas Scheff (2000), pozawerbalnym znakiem świadczącym o próbie maskowania wstydu ${ }^{5}$.

5 Pozostałe sygnały niewerbalne świadczące według autorów o próbie panowania nad wstydem to na przykład: przygryzanie lub oblizywanie ust, przygryzanie języka, poziome lub pionowe marszczenie czoła. 


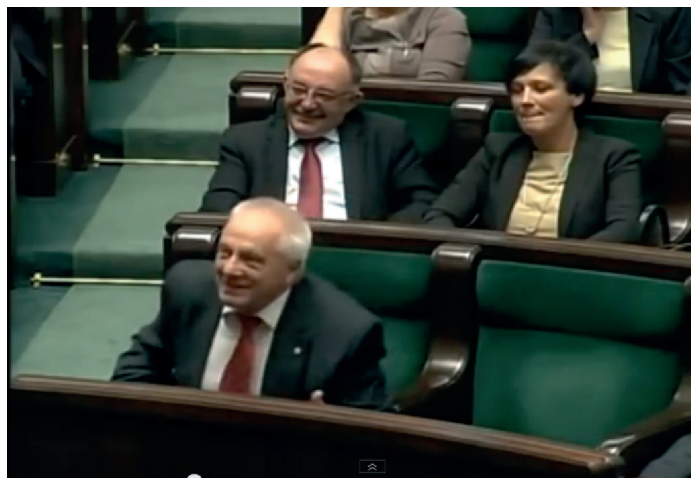

Fot. 20. Poseł Niesiołowski zwraca się do przemawiającego posła Jakiego: „Naucz się biologii, nieuku!”

Źródło: www.youtube.comwatchv=0JPMMiYp5-Y

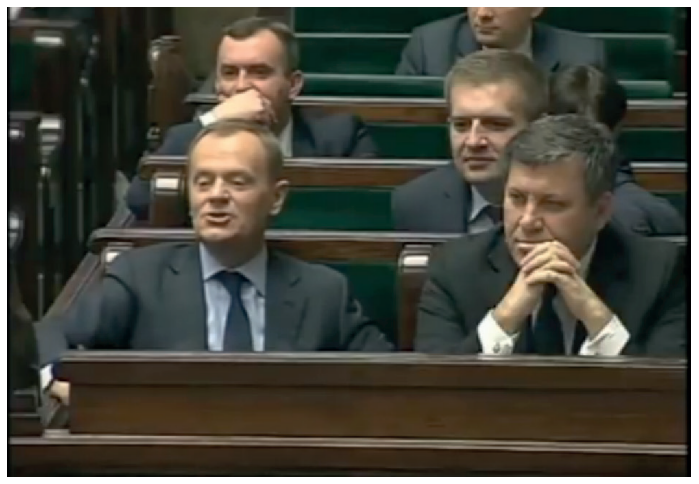

Fot. 21. Premier Tusk zwraca się do przemawiającego posła Kaczyńskiego. Ze względu na brak mikrofonu wypowiedziane słowa są dla telewidzów niezrozumiałe Źródło: www.youtube.comwatchv=GroeGfOijWI

W trakcie dyskusji sejmowej pomiędzy premierem Tuskiem a posłem Kaczyńskim, ironiczny śmiech ze strony sali dało się słyszeć w trakcie obu wystąpień. Reakcję tę wywołały słowa premiera („Trzeba mieć w sobie coś z rycerza, żeby stanąć w obronie 
pacjentów", mowa o działaniach PO, śmiech partii opozycyjnych) oraz słowa Jarosława Kaczyńskiego (który stwierdza, że był zaskoczony, iż „[... pan premier był łaskaw zwracać się” w swoim wystąpieniu do niego wielokrotnie, śmiech premiera i ministrów, www.youtube.comwatchv=kLrM-SOfpjk).

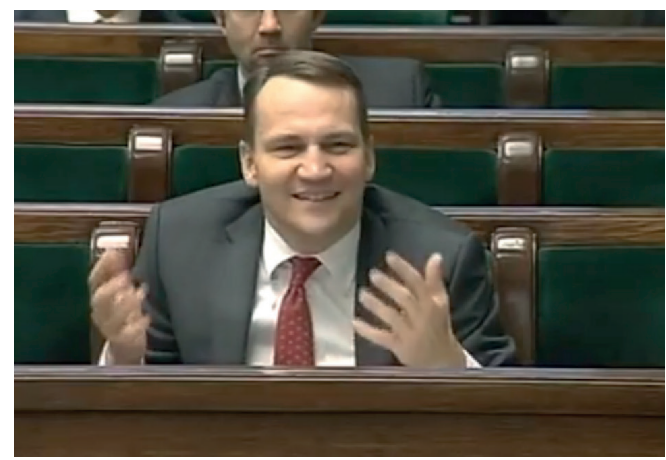

Fot. 22. Minister Sikorski reaguje niedowierzaniem na bezpodstawne jego zdaniem hipotezy posła Antoniego Macierewicza Źródło: www.youtube.comwatchv=U50pQyldJto

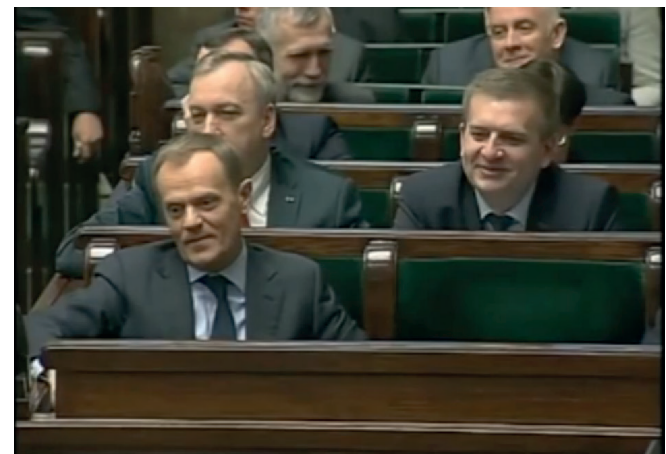

Fot. 23. Ministrowie reagują śmiechem na wystąpienie Jarosława Kaczyńskiego Źródło: www.youtube.comwatchv=kLrM-SOfpjk 
Ostatnim opisywanym sposobem na okazanie dezaprobaty wobec słów przemawiającego jest ostentacyjne opuszczenie sali. Posłowie PiS wychodzą z sali obrad po tym, jak poseł Palikot zasugerował, że miejsce posłów tego klubu jest w więzieniu. Marszałek Sejmu zwróciła wtedy uwagę posłom na nieobyczajność ich zachowania (opuszczali salę w trakcie wystąpienia innego posła, będąc jednocześnie zwróceni do niego plecami).

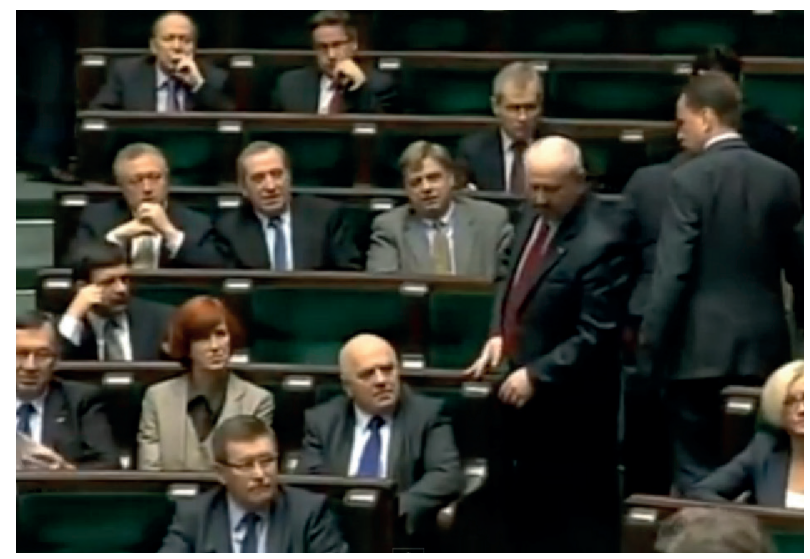

Fot. 24. Ministrowie PiS opuszczają salę w trakcie wystąpienia posła Palikota Źródło: www.youtube.comwatchv=G8IMe-OxoT4

Całokształt zachowań publiczności sejmowej odnieść można do praktyk obronnych opisywanych przez E. Goffmana (2008: 239). Lojalność partyjna przejawia się w lojalności dramaturgicznej, czyli moralnym zobowiązaniu wobec zespołu do samokontroli $\mathrm{w}$ trakcie trwania interakcji. To zobowiązanie narzuca publiczności dyscyplinę dramaturgiczną polegającą na umiejętności stłumienia spontanicznych reakcji na błędy partnerów (w przypadku posiedzeń sejmowych - reakcja na błędy członków własnego klubu). W przypadku występujących, dyscyplina dramaturgiczna przejawia się w umiejętności odpowiedniej 
reakcji na nieoczekiwane zachowania publiczności. Zdyscyplinowany mówca, wykazujący się rozwagą dramaturgiczną potrafi przewidzieć i zaprojektować najlepszą inscenizację widowiska. Sytuacja wystąpienia sejmowego wymaga szczególnej rozwagi ze względu na publiczność partii opozycyjnej, która bezlitośnie uwypukla ewentualne wpadki i pomyłki (Goffman 2008: 254).

\section{Podsumowanie}

Pomimo że sala sejmowa uznana może być za sferę publiczną, czyli przestrzeń najbardziej otwartą dla jednostek, to ze względu na regulacje prawne oraz tradycję, nałożonych jest na nią szereg ograniczeń (Leathers 2006: 123). Na podstawie niniejszej analizy stwierdzić należy, że przestrzeń społeczna posiedzeń sejmowych, zarówno w jej proksemicznym, jak i interakcyjnym wymiarze, jest przestrzenią zrutynizowaną oraz sztywno, odgórnie zdefiniowaną. Fizyczny wymiar przestrzeni sprzyja rutynizacji działań aktorów.

Na sali sejmowej istnieje niewielka swoboda w doborze miejsc w mikroprzestrzeni przez aktorów społecznych. Granice w obrębie sali sejmowej nie są przypadkowe, oddzielają politycznych oponentów, jednocześnie integrując posłów w obrębie jednej partii. Jasny podział na centrum i peryferia uzyskany został dzięki specyficznemu usytuowaniu miejsc kluczowych dla zgromadzenia (podwyższenie dla rządu; podwyższenie mównicy i miejsca dla marszałka; miejsca siedzące skierowane w stronę mównicy). Środowisko proksemiczne sali sejmowej jest zatem silnie ustrukturyzowaną i skonwencjonalizowaną przestrzenią. Oddziałuje ono na aktorów społecznych, sprzyjając kierowaniu uwagi, emocji oraz działań w jasno określony sposób. Podział na cen-

6 Pozostałe rodzaje terytoriów to sfera domowa oraz sfera interakcyjna (obejmująca nasze ciało). 
trum (scenę) oraz peryferia (publiczność) nasuwa skojarzenia ze spektaklem, który odgrywany jest ze ściśle zaplanowanym scenariuszem, w specyficznie zaplanowanej aranżacji. W przypadku nieprzestrzegania reguł Marszałek Sejmu ma prawo przywołać posłów do porządku, przypomnieć o panujących zasadach oraz w wyjątkowych sytuacjach nałożyć odpowiednie kary ${ }^{7}$. E. Goffman zauważa, że uczestnicy interakcji dbają o utrzymanie zgody co do spójnej definicji sytuacji. Dzieje się tak również wtedy, gdy sytuacja zostaje stworzona w celu umożliwienia wyrażenia różnic $\mathrm{w}$ opiniach aktorów. Pomimo odmiennych stanowisk istnieje wśród aktorów społecznych porozumienie ustanawiające dopuszczalne środki ekspresji, słownictwo i ton wypowiedzi (Goffman 1981: 39).

Publiczność obrad sejmowych, stanowiąca przestrzeń społeczną obrad Sejmu w wymiarze interakcyjnym, może pełnić zarówno pasywną, jak i aktywną rolę. Z jednej strony, jak pisze E. Goffman (2008: 122), publiczność wystawia zespołowe przedstawienie (wspomniane odgrywanie uznania bądź dezaprobaty dla przemawiającego). Z drugiej strony, świadomość istnienia publiczności, czyli osób, które na bieżąco oglądają i oceniają wystąpienia, wpływa na zachowanie przemawiających polityków, skłania ich do stosowania werbalnych oraz niewerbalnych komunikatów mających na celu zdobycie przychylności słuchaczy. Wyraziste, ogólne słownictwo, prosta, logiczna składnia, zwięzłość i skrótowość tekstów, redukcja skomplikowanej terminologii czy wreszcie daleko idąca konwencjonalizacja języka polityków mają sprawić, że będą oni przez widzów postrzegani jako wyraziciele ich opinii oraz przedstawiciele interesów wyborców.

7 Działo się tak między innymi wtedy, gdy Premier Donald Tusk zarzucit politykom PiS kłamstwo w sprawie sprzedaży mysłowickiego szpitala. W odpowiedzi prezes PiS Jarosław Kaczyński nazwał z mównicy sejmowej członków PO partią „złodziei i oszustów”. Marszałek Kopacz skierowała słowa posła Kaczyńskiego do Komisji Etyki. 
Mediatyzacja polityki sprawia, że uwaga przeciętnego odbiorcy jest przyciągana przez przywoływanie skandali, konfliktów czy przestępstw (Łabędź 2013: 9). Dodatkowo, politycy starają się o pozytywny odbiór swojej osoby poprzez odpowiednie komunikaty niewerbalne. Asertywna i stanowcza postawa ciała sprawia, że ich słowa są odbierane jako bardziej wiarygodne. Zarówno werbalne, jak i niewerbalne komunikaty występujących w telewizji polityków muszą być stale dostosowywane do wymogów mediów masowych. Emocjonalna warstwa komunikatów staje się bardzo ważna w kontekście stałej tendencji do upraszczania i trywializowania nadawanych przez polityków treści. Konsekwencją wzrostu znaczenia przekazów telewizyjnych w życiu politycznym jest medialny aspekt legitymizacji władzy, który staje się równie istotny co legitymizacja wyborcza będąca rezultatem demokratycznych wyborów. Atrakcyjność wizerunku telewizyjnego, na którą składają się charyzma, atrakcyjność wystąpień oraz swoboda i naturalność w prezentowaniu własnej osoby, w ogromnym stopniu warunkuje sukcesy na scenie politycznej (Fras 2005: 46). Umiejętność eksponowania określonych emocji i ukrywanie przed publicznością niepożądanych reakcji są cennym kapitałem politycznym. W związku ze stałą obecnością publiczności praca nad emocjami (zob. Hochschild 2009) staje się nieodłączną częścią pracy parlamentarzysty.

Publiczność zgromadzona na sali sejmowej stanowi pewnego rodzaju tło dla rozgrywających się wydarzeń. Opisywana przestrzeń ma wymiar nie tylko materialny, lecz także „[...] symboliczny, ponieważ naznaczona jest przez emocje, uczucia i wartości” (Jałowiecki 2002: 243). Przypisane miejscu znaczenia oddziałują na zachowania zbiorowe i podzielane emocje. Zwolennicy jednej partii pozostając w bliskości fizycznej, są bardziej skłonni do naśladownictwa oraz jednomyślności w wyrażaniu zarówno pozytywnych, jak i negatywnych emocji. Pozornie żywiołowe reakcje mają krytyczny bądź aprobujący wydźwięk dla 
wypowiedzi posłów. Charakter zachowań zależny jest od solidarności wewnątrzpartyjnej oraz istniejących sojuszy międzypartyjnych. Reakcje publiczności są zatem skonwencjonalizowane, nastawione na budowanie określonego obrazu konkretnego polityka czy całej partii, często brakuje im naturalnej spontaniczności. Parlamentarzyści jednego ugrupowania odgrywają swoje role i współpracują w sprawnej inscenizacji wielu fragmentów wystąpienia, stanowią z e s p ó ł w myśl definicji tego pojęcia, którą E. Goffman (1981: 109) zawarł w książce Człowiek w teatrze życia codziennego. Wysoce skodyfikowane interakcje są odgrywane w sposób przewidywalny zarówno dla polityków, jak i dla publiczności zgromadzonej przed telewizorami ${ }^{8}$.

Podsumowując, należy zastanowić się, w jaki sposób sztywna i odgórnie zdefiniowana przestrzeń społeczna obrad sejmowych wpływać może ma konstruktywną i płodną debatę polityczną. Edward Hall (1997: 167) opisując zagadnienie proksemiki, dokonuje rozróżnienia na przestrzeń dospołeczną - która sprzyja interakcjom, oraz odspołeczną - utrudniającą stosunki międzyludzkie. Na podstawie przeprowadzonej analizy można stwierdzić, iż niektóre z proksemicznych aspektów sali sejmowej mają raczej charakter przestrzeni odspołecznej. Kontekstowe zorganizowanie roli zakłada sztywne trzymanie się wzorców postępowania wypracowanych przez grupę (Goffman 1981: 103), w przypadku polityków są to konflikt i krytyka międzypartyjna oraz solidarność w obrębie własnej partii.

8 Potwierdzeniem wypracowywania wspólnego stanowiska są codzienne briefy przygotowywane dla polityków przez władze partii i ekspertów do spraw komunikacji medialnej. Partyjne instrukcje dokładnie opisują, jakie opinie powinni prezentować politycy i jakich udzielać komentarzy do bieżących wydarzeń. „Wspólny głos” buduje u telewidzów wizerunek wewnątrzpartyjnej solidarności i jedności. Źródło: http://www. tvn24.pl/wiadomosci-z-kraju,3/brief-na-temat-briefu-pis-z-wytycznymi-jak-komentowac-wpadke-z-partyjna-instrukcja,493406.html [dostęp 13.04.2015]. 
Analizując przedstawione cechy przestrzeni społecznej, można odnieść wrażenie, że środowisko proksemiczne i publiczność izby mniejszej parlamentu bardziej sprzyjają odgrywaniu założonych ról, które zgodne są z wizerunkowym scenariuszem, niż pomagają w owocnej debacie ponad politycznymi podziałami.

\title{
AUDIENCE AND PROXEMICS OF PARLIAMENTARY PERFORMANCES. SELECTED ASPECTS OF SOCIAL SPACE IN THE POLISH SEJM
}

\begin{abstract}
The purpose of this research is to describe the social space of parliamentary speeches. There are two key aspects of the social space mentioned in the article. First aspect refers to the audience of parliamentary performances. Second aspect raises the question of proxemics in the Polish Sejm. Physical space with its centre, peripherals, backstage and borders influence upon social interaction. This research highlights the importance of the social space in shaping the character and quality of Parliamentary debate.
\end{abstract}

Key words: social space, proxemics, audience, audience reactions, emotions and interactions, parliamentary performances

\section{Bibliografia}

Bierwiaczonek, Krzysztof (2007), Przestrzenie znaczace i puste. Percepcja przestrzeni miejskiej Będzina, Cieszyna, Mikołowa i Żywca, [w:] Socjologia miasta - nowe dziedziny badań, red. Andrzej Majer, Wydawnictwo Uniwersytetu Łódzkiego, Łódź, s. $123-141$

Brand, Jay L. (2009), Physical Space and Social Interaction, Haworth, http:// workwellpartners.com/wp-content/ uploads/2014/10/Physical-Space. pdf [dostęp 04.01.2015]
Brief na temat briefu. PiS z wytycznymi, jak komentować wpadkę z partyjng instrukcja, http://www.tvn24.pl/wiadomosci-z-kraju,3/brief-na-temat-briefu-pis-z wytycznymi-jak-komentowac-wpadke-z-partyjna-instrukcja,493406.html [dostęp 04.01.2015]

Bugni, Valerie, Ronald Smith (2006), Symbolic interaction theory and architecture, University Libraries, University of Nevada, Las Vegas, http://digitalscholarship.unlv.edu/ cgi/viewcontent.cgi?article $=1004 \&$ - 
context=sociology_pubs [dostęp 04.01.2015]

Cobel-Tokarska, Marta (2012), Przestrzeń społeczna: świat - dom - miasto, [w:] Krótkie wykłady z socjologii, red. Elżbieta Tarkowska, Anna Firkowska-Mankiewicz, Tatsiany Kanash, Akademia Pedagogiki Specjalnej, Warszawa, s. 45-62

Fras, Janina (2005), Komunikacja polityczna. Wybrane zagadnienia gatunków i języka wypowiedzi, Wydawnictwo Uniwersytetu Wrocławskiego, Wroctaw

Furman, Wojciech, Andrzej Kaliszewski, Kazimierz Wolny-Zmorzyński (2006), Gatunki dziennikarskie. Teoria, praktyka, język, Wydawnictwa Akademickie i Profesjonalne, Warszawa

Goffman, Erving (1981), Człowiek w teatrze życia codziennego, Państwowy Instytut Wydawniczy, Warszawa

Goffman, Erving (2008), Zachowanie w miejscach publicznych, Wydawnictwo Naukowe PWN, Warszawa

Hall, Edward (1997), Ukryty wymiar, Warszawskie Wydawnictwo Literackie MUZA SA, Warszawa

Hochschild, Arlie Russell (2009), Zarzqdzanie emocjami. Komercjalizacja ludzkich uczuć, Wydawnictwo Naukowe PWN, Warszawa

Jałowiecki, Bohdan (2002), Przestrzeń społeczna, [w:] Encyklopedia socjo- logii, t. 3, red. Zbigniew Bokszański, Krzysztof Gorlach i in., Oficyna Naukowa, Warszawa, s. 241-244

Jałowiecki, Bohdan, Marek S. Szczepański (2006), Miasto i przestrzeń w perspektywie socjologicznej, Wydawnictwo Naukowe Scholar, Warszawa

Leathers, Dale (2007), Komunikacja niewerbalna, Wydawnictwo Naukowe PWN, Warszawa

Łabędź, Krzysztof (2013), Patologie w języku polityków - uwarunkowania, rodzaje, skutki, [w:] Język polityków $i$ jego patologie, red. Krzysztof Łabędź, Księgarnia Akademicka, Kraków, s. 7-18

Rapley, Tim (2010), Analiza konwersacji, dyskursu i dokumentów, PWN, Warszawa

Retzinger, Suzanne, Thomas Scheff (2000-2001), Emotion, alienation, and narratives: resolving intractable conflict, www.soc.ucsb.edu/faculty/ scheff $/$ main.php?id=16.html [dostęp 04.01.2015]

Skarżyńska, Monika (2011), Język reportażu telewizyjnego, Semper, Warszawa

Wallis, Aleksander (1990), Socjologia przestrzeni, Niezależna Oficyna Wydawnicza, Warszawa

Yi-Fu, Tuan (1987), Przestrzeń i miejsce, Państwowy Instytut Wydawniczy, Warszawa 